\title{
Analisis Ketersediaan Air Permukaan dan Proyeksi Kebutuhan Air DAS Bo- dri Tahun 2040
}

\author{
Chafda Larasati, Aji Wijaya Abadi, Galih Prakosa, Novanna Dwi Septyo A, Venny Vivid F, Wisha Putri M, Wiwik \\ Widyaningrum dan M Pramono Hadi
}

Departemen Geografi Lingkungan, Fakultas Geografi, Universitas Gadjah Mada, Yogyakarta, Indonesia

*Email koresponden: chafdalarasati@mail.ugm.ac.id

Direvisi: 2020-12-23 . Diterima: 2021-02-18

(c)2021 Fakultas Geografi UGM dan Ikatan Geograf Indonesia (IGI)

\begin{abstract}
Abstrak Sumberdaya air penting untuk pemenuhan kebutuhan semua makhluk hidup termasuk manusia. DAS Bodri menyediakan suplai air permukaan melalui sungai-sungai yang ada dalam DAS, yang dapat dimanfaatkan oleh penduduk sekitar. Seiring berjalannya waktu, DAS Bodri mengalami perubahan penggunaan lahan yang menyebabkan terjadinya peningkatan kebutuhan air dan terjadi ketidakseimbangan antara kebutuhan dan ketersediaan air permukaan. Tujuan dari penelitian ini, yaitu mengetahui keseimbangan antara kebutuhan air di masa yang akan datang dengan ketersediaan air permukaan di DAS Bodri tahun 2040. Perhitungan keseimbangan antara kebutuhan dan ketersediaan air permukaan dilakukan dengan membandingkan antara kebutuhan air total dan ketersediaan air permukaan. Parameter kebutuhan air total terdiri dari kebutuhan air domestik, fasilitas kesehatan, fasilitas pendidikan, fasilitas peribadatan, perkantoran, industri, pertokoan dan pasar, warung makan, peternakan, irigasi, dan tambak. Kebutuhan air di tahun mendatang diketahui melalui proyeksi secara eksponensial dan tetap dari data jumlah dalam perhitungan parameter. Kebutuhan air untuk aktivitas domestik dan nondomestik diestimasikan mencapai 2,44 miliar $\mathrm{m}^{3}$ pada tahun 2040. Hasil analisis neraca air menunjukkan bahwa status neraca air DAS Bodri tahun 2010 -2019 mengalami defisiensi. Hal tersebut menunjukkan bahwa potensi sumberdaya air permukaan masih belum mencukupi untuk pemenuhan kebutuhan air di DAS Bodri hingga tahun 2040.
\end{abstract}

Kata kunci: DAS Bodri, Ketersediaan Air Permukaan, Kebutuhan Air, Neraca Air

\begin{abstract}
Water resources play an important role in meeting the needs of all living things, including humans. The Bodri watershed provides surface water supply through rivers on the watershed, which the local residents can use and utilize. Over time, the Bodri watershed underwent landuse change, which led to an increase in water demand, resulting in an imbalance between water demand and surface water availability. Calculation of the balance between demand and surface water availability is done by comparing the total water demand and the surface water availability. This study aims to determine the balance between future water demand and surface water availability in the Bodri watershed in 2040. The parameters used to determine total water demand consist of water needs of the following sectors; domestic, health facilities, educational facilities, religious facilities, offices, industry, shops and markets, food stalls, livestock, irrigation, and ponds. In the coming year, water demand is known through projections exponentially and permanently from the amount of data in the calculation of parameters. Water demand for domestic and nondomestic activities is estimated to reach 2.44 billion $m 3$ in 2040. The water balance analysis results show that the status of the Bodri watershed water balance in 2010-2019 is deficient. The potential for surface water resources is still insufficient to meet the water needs in the Bodri watershed until 2040.
\end{abstract}

Keywords: Bodri Watershed, Surface Water Availability, Water Needs, Water Balance

\section{PENDAHULUAN}

Air merupakan sumberdaya yang sangat penting bagi makhluk hidup khususnya manusia guna memenuhi kebutuhan rumah tangga (domestik), pertanian, perikanan, industri, pariwisata, dan lainnya. Untuk itu, ketersediaan air di bumi memerlukan sifat keberlanjutan agar dapat digunakan untuk masa yang akan datang atau antargenerasi. Sifat keberlanjutan air dapat dipertahankan dengan pengelolaan yang tepat dan berkaitan dengan distribusinya (Kumalajati dkk, 2015). Menurut UN-Water dalam PTSMI (2015), kurang dari $1 \%$ total sumberdaya air tawar di bumi atau sekitar 200 ribu $\mathrm{km}^{3}$ air dapat digunakan oleh manusia akan tetapi tidak terdistribusi secara merata. Sekitar 780 juta manusia di dunia tidak memiliki akses terhadap air bersih dan 80 juta diantaranya adalah penduduk Indonesia. Indonesia Water Investment Roadmap 2011-2014 dalam PTSMI (2015) menyatakan bahwa hanya $47,71 \%$ dari total penduduk indonesia yang mendapatkan akses sumber air.

Kebutuhan manusia akan sumberdaya air disediakan dalam suatu sistem Daerah Aliran Sungai (DAS). Sumberdaya air permukaan (sungai, waduk, rawa) memiliki potensi dalam menyuplai air untuk memenuhi kebutuhan air. Oleh karena itu, diperlukan analisis sumberdaya air sehingga 
pemanfaatan air dapat dilakukan dengan optimal dan dapat dilakukan pengelolaan yang tepat agar ketersediaan air dapat terjaga.

Penelitian ini berlokasi di DAS Bodri (Gambar 1), sehingga secara geografis lokasi yang digunakan dalam analisis hanyalah kecamatan/desa yang terletak di wilayah DAS Bodri. Secara administratif DAS Bodri terletak di 4 wilayah kabupaten, yaitu Kabupaten Temanggung (4 kecamatan), Kabupaten Kendal (12 kecamatan), Kabupaten Wonosobo (1 Kecamatan), dan Kabupaten Semarang (3 kecamatan). Sungai Bodri ini memiliki sejumlah anak sungai besar yakni Sungai Penggung, Sungai Logung, Sungai Ringin, Sungai Kaliputih, Sungai Kalipupu, Sungai Lowungu, Sungai Trocoh, dan Sungai Manggung.

DAS Bodri merupakan salah satu DAS yang termasuk DAS prioritas berdasarkan Keputusan Menteri Kehutanan RI No. SK.328/Menhut-II/2009 tentang Penetapan DAS Dalam Rangka RPJM Tahun 2010-2014 (Emilia dkk, 2013). DAS Bodri dibagi menjadi 4 bagian sub DAS, yakni sub DAS Lutut, sub DAS Logung, sub DAS Putih dan sub DAS Bodri Hilir dengan total luas keseluruhan DAS yakni 65.248,54 Ha. Berdasarkan data Stasiun Klimatologi Juwero yang terletak di DAS Bodri sepanjang tahun 2009-2015 (Gambar 2) wilayah ini memiliki curah hujan rerata tahunan sebesar $2.148 \mathrm{~mm} /$ tahun dengan nilai curah hujan tertinggi sebesar $2.968 \mathrm{~mm} /$ tahun di tahun 2010 dan nilai curah hujan terdendah sebesar $1.423 \mathrm{~mm} /$ tahun di tahun 2015.

Secara hidrogeologi, potensi airtanah di daerah DAS Bodri tersusun atas kesatuan sistem Cekungan Airtanah (CAT) Kendal di bagian tengah dan hilir DAS yang terbagi menjadi 3 satuan hidrogeologi, yakni setempat akuifer produktif, akuifer produktivitas kecil dan akuifer daerah airtanah langka (Gambar 3). Akuifer produktif menyimpan potensi airtanah

\section{PETA DAERAH ALIRAN SUNGAI BODRI JAWA TENGAH}

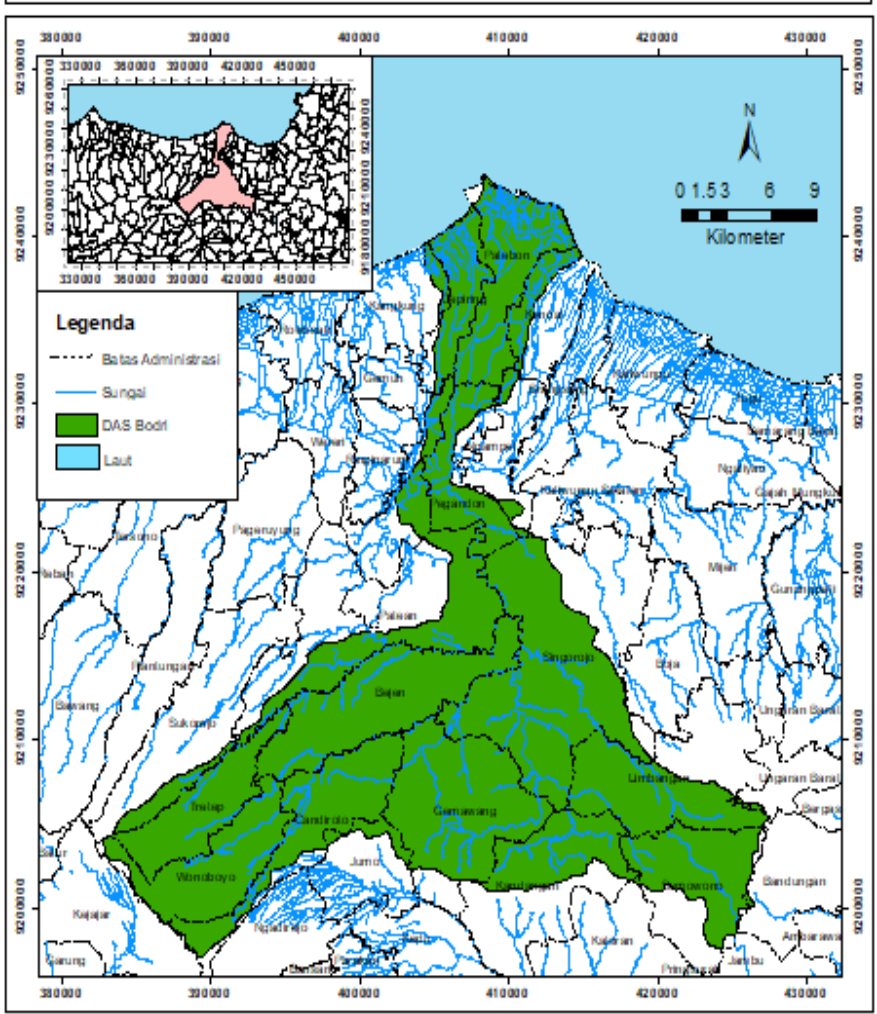

Gambar 1. Daerah Aliran Sungai (DAS) Bodri Jawa Tengah yang tinggi hingga sedang, akuifer produktif meliputi wilayah CAT Kendal dari timur ke barat yang terkonsentrasi pada bagian tengah. Akuifer produktivitas kecil dan akuifer daerah airtanah langka menyimpan potensi airtanah yang kecil hingga sukar ditemukan, akuifer produktivitas rendah dan akuifer daerah airtanah langka meliputi wilayah CAT Kendal bagian selatan.

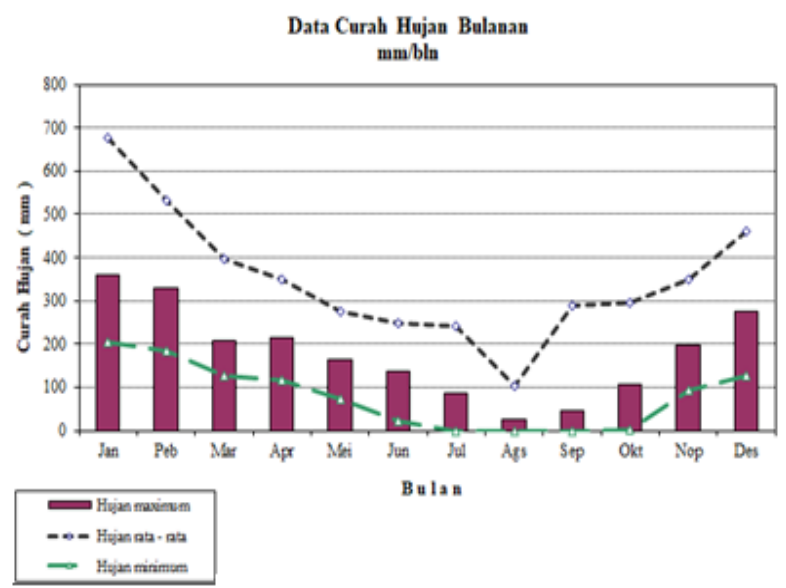

Gambar 2. Rerata curah hujan bulanan tahun 2009-2015 Stasiun Klimatologi Juwero DAS Bodri Sumber: Dinas Pusdataru Jawa Tengah, 2018

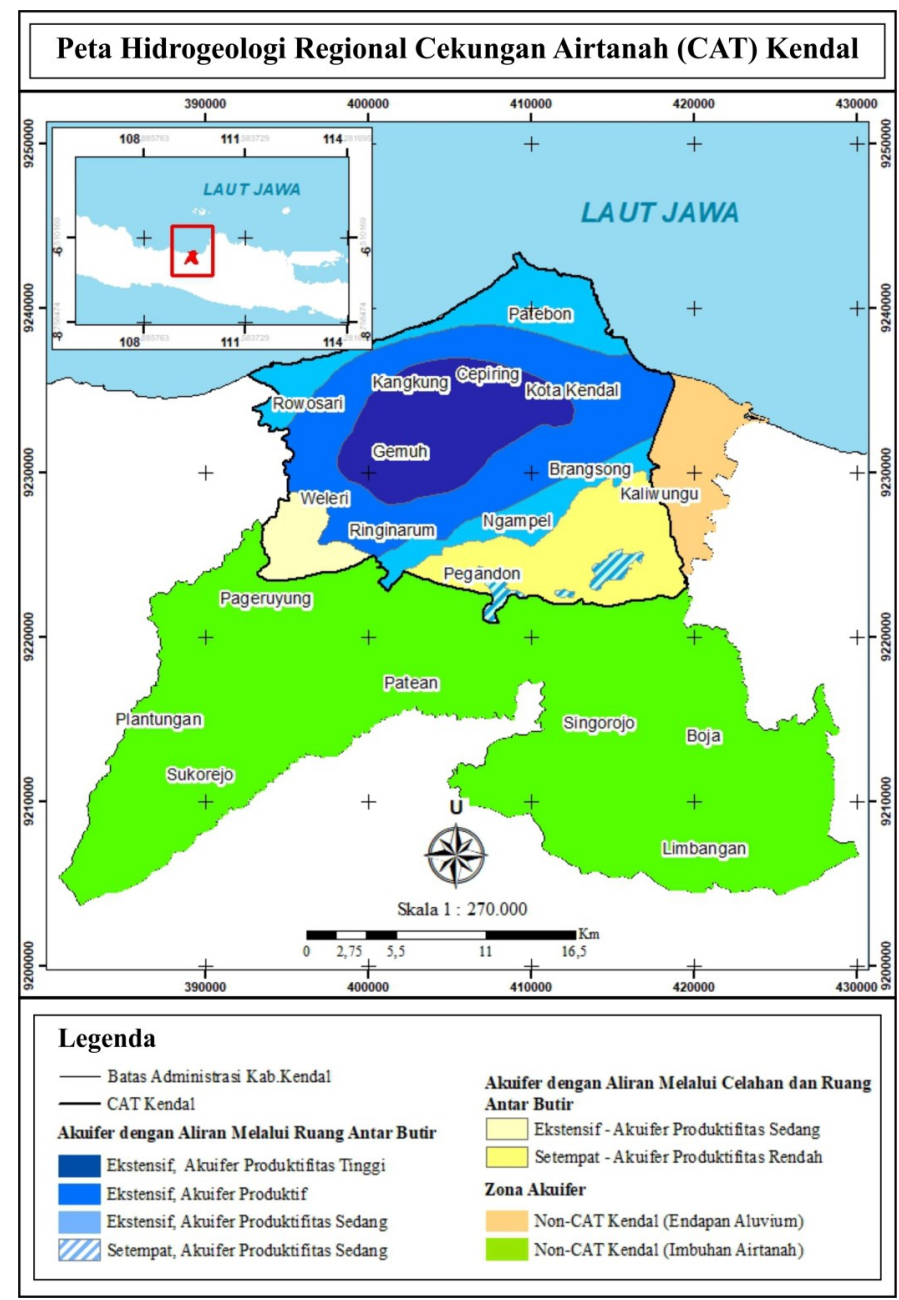

Gambar 3. Peta Hidrogeologi CAT Kendal Sumber: Effendi, A dan Tabrani, 1985 dalam Hasmannoor (2018) 
Berdasarkan penelitian Tisnasuci dkk. (2021), DAS Bodri mengalami perubahan tutupan lahan dari tahun 2016 hingga tahun 2020 yang ditunjukkan dengan adanya peningkatan luas permukiman, perkebunan, lahan terbuka, dan penurunan luas hutan produksi. Selain itu, seiring dengan perkembangan wilayah di DAS Bodri termasuk pertumbuhan penduduk maka aktivitas sosial ekonomi di DAS Bodri juga semakin banyak. Hal ini berpengaruh terhadap peningkatan jumlah kebutuhan air untuk memenuhi aktivitas tersebut baik kebutuhan domestik maupun non domestik. Akan tetapi, peningkatan kebutuhan air tersebut tidak mempertimbangkan aspek ketersediaan air yang semakin kritis (Sudarmadji dkk, 2014).

Berbagai aktivitas di DAS Bodri seperti aktivitas permukiman, pertanian dan industri diperkirakan telah memicu terjadinya kerusakan sumberdaya alam dan lingkungan. Salah satu dampak yang ditimbulkan dari kerusakan sumberdaya alam tersebut adalah ketidakseimbangan antara kebutuhan dan ketersediaan air. Hal ini dikarenakan ketersediaan air khususnya air permukaan yang cenderung tetap sedangkan kebutuhan air terus mengalami peningkatan. Menurut Sitompul dan Efrida (2018), keseimbangan sumberdaya air dapat dicapai dengan upaya pengkajian komponen-komponen kebutuhan air dan efisiensi penggunaan air.

Mengingat kecenderungan ketersediaan air khususnya air permukaan yang tetap sedangkan kebutuhan yang terus meningkat, agar tidak terjadi kekurangan air maka harus segera dilakukan upaya-upaya pengelolaan sumberdaya air dan efisiensi penggunaan air. Upaya yang dapat dilakukan apabila terjadi kekurangan air di DAS Bodri adalah dengan merencanakan pembangunan Waduk Bodri untuk memenuhi kebutuhan air baku di wilayah DAS Bodri. Berdasarkan
BBWS Pemali Juana (2018) Waduk Bodri diperkirakan mampu menampung 41,82 juta $\mathrm{m}^{3}$ air yang diharapkan mampu memenuhi kebutuhan air di DAS Bodri pada tahun 2022.

Tujuan dari penelitian ini yaitu mengetahui keseimbangan antara kebutuhan air di masa yang akan datang dengan ketersediaan air permukaan di DAS Bodri tahun 2040. Untuk itu, diperlukan analisis kebutuhan dan ketersediaan air permukaan DAS Bodri untuk mengetahui jumlah kelebihan dan kekurangan air dalam memenuhi kebutuhan air di masa mendatang. Hasil analisis kebutuhan dan ketersediaan air permukaan DAS Bodri dapat dijadikan masukan dalam menentukan kebijakan dan penyusunan RTRW yang berkelanjutan di DAS Bodri.

\section{METODE PENELITIAN}

Pengumpulan data dalam penelitian dilaksanakan dengan menggunakan data sekunder berupa dokumen resmi dari lembaga Pemerintah Daerah Kabupaten Kendal. Selain mengolah data yang diterbitkan oleh lembaga pemerintah, dilakukan pengumpulan data berupa studi pustaka dari penelitian dan karya ilmiah sebelumnya, untuk dapat memahami lebih jauh mengenai metode yang digunakan. Alur penelitian persediaan air dan proyeksi kebutuhan air DAS Bodri tahun 2040 sebagai berikut (Gambar 4).

\section{Kebutuhan Air}

Proyeksi kebutuhan air DAS Bodri dilakukan dengan menggunakan rumus yang diperoleh dari Kriteria Perencanaan Ditjen Cipta Karya (Dinas Pekerjaan Umum, 1996) dan dengan menggunakan standar SNI 19-6728.12002. Data-data sosial dan ekonomi untuk perhitungan

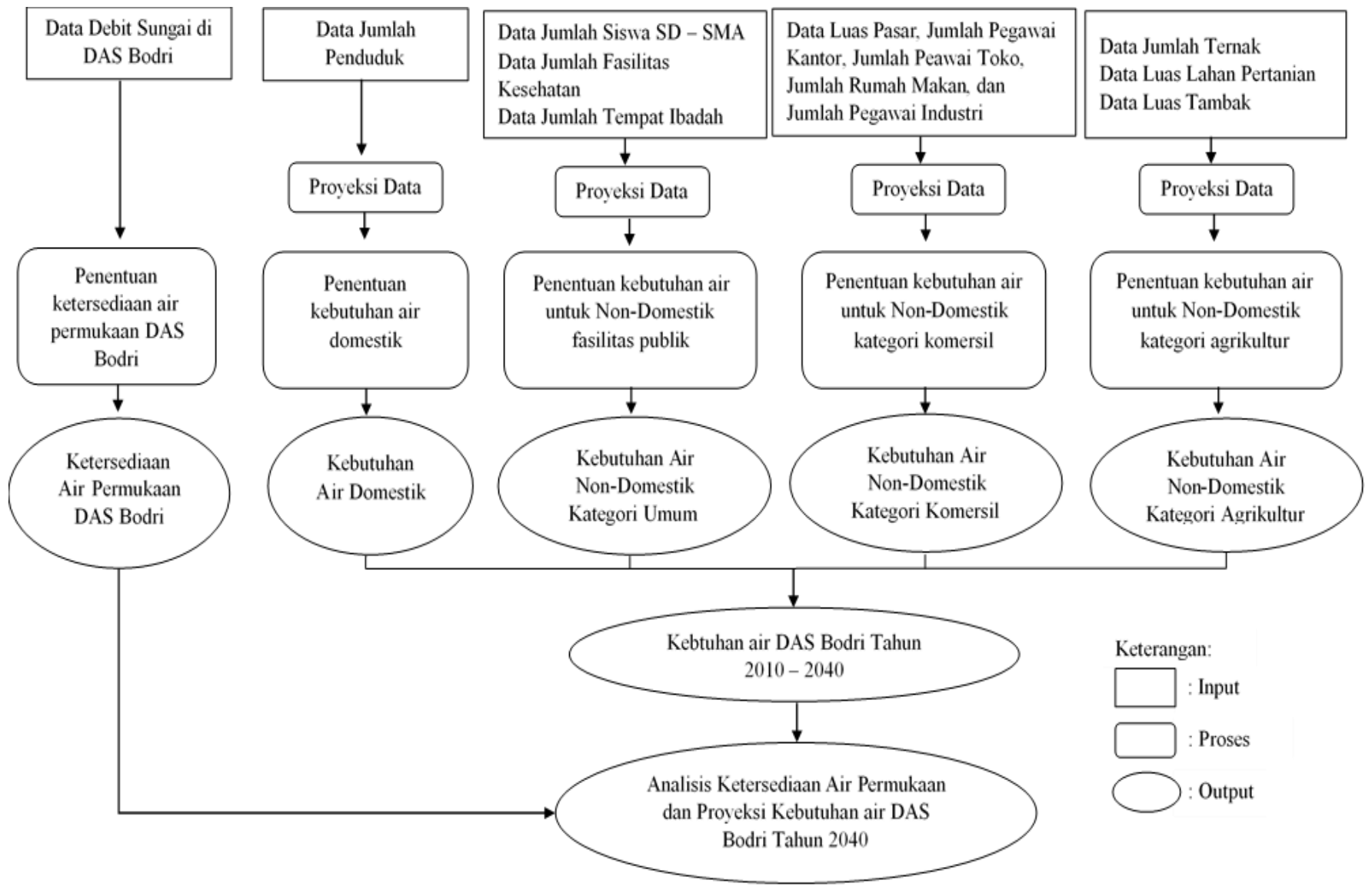

Gambar 4. Diagram Alir Penelitian 
kebutuhan air didapatkan dari publikasi Badan Pusat Statistik (BPS) Kabupaten Kendal, Semarang, Temanggung, dan Wonosobo tahun 2011 - 2020. Kebutuhan air dibagi menjadi dua kategori yakni kebutuhan air domestik dan kebutuhan air non-domestik.

Kebutuhan air domestik dihitung dengan menggunakan parameter jumlah penduduk. Kebutuhan air non-domestik dihitung dengan menggunakan parameter fasilitas kesehatan, fasilitas pendidikan, fasilitas peribadatan, perkantoran, pertokoan, warung makan, peternakan, dan irigasi. Setiap kebutuhan mempunyai standar pemakaian air yang berbedabeda seperti yang ditunjukkan pada Tabel 1.

Kebutuhan air total DAS Bodri merupakan jumlah kebutuhan air seluruh sektor. Perhitungan kebutuhan air dilakukan menggunakan rumus:

\section{Kebutuhan Air Domestik}

Kebutuhan air domestik dihitung berdasarkan kebutuhan air konsumsi berdasarkan standar kebutuhan air konsumsi pedesaan yaitu $60 \mathrm{Lt} /$ hari. Kebutuhan air domestik dihitung dengan menggunakan rumus persamaan (1):

$\mathrm{Qd}=365$ hari $\times[\mathrm{q}(\mathrm{u}) \times 1 / 1.000 \times \mathrm{P}(\mathrm{u})]$.

\section{Keterangan:}

Qd = konsumsi air domestik ( $\mathrm{m}^{3} /$ tahun)

$\mathrm{q}(\mathrm{u})=$ konsumsi air per kapita (Lt/kapita/hari)

$\mathrm{P}(\mathrm{u}) \quad=$ jumlah penduduk

Sumber: SNI 19-6728.1-2002 Penyusunan Neraca Sumber Daya (2002)

\section{Kebutuhan Air Fasilitas Kesehatan}

Kebutuhan air pada sektor fasilitas kesehatan berdasarkan jumlah bed untuk rumah sakit dan puskesmas, dimana standar kebutuhan air untuk puskesmas sebesar $200 \mathrm{Lt} / \mathrm{unit} /$ hari dan $2000 \mathrm{Lt} / \mathrm{bed} /$ hari untuk rumah sakit. Perhitungan kebutuhan air sektor fasilitas kesehatan dilakukan menggunakan rumus persamaan (2) sebagai berikut:
Qs $(\mathrm{RS})=\Sigma$ bed $\mathrm{x} 365$ hari $\mathrm{x} \mathrm{q}(\mathrm{srs}) / 1.000$

Dari persamaan (2) dapat dirumuskan menjadi persamaan (3).

Qs (puskesmas) $=\Sigma$ unit x 365 hari $\mathrm{x} \mathrm{q}(\mathrm{sp}) / 1.000$...

Sehingga dapat di rumuskan secara sederhana sebagai persamaan (4).

$\mathrm{Q} s=\mathrm{Q}$ ( puskesmas) + Qs (RS)

\section{Keterangan:}

Qs= konsumsi air untuk fasilitas kesehatan ( $\mathrm{m}^{3} /$ tahun)

Qs (RS)= adalah konsumsi air untuk fasilitas kesehatan rmah sakit ( $\mathrm{m}^{3} /$ tahun)

Qs (puskesmas) $=$ adalah konsumsi air untuk fasilitas kesehatan puskesmas ( $\mathrm{m}^{3} /$ tahun)

$\mathrm{q}(\mathrm{srs})=$ adalah konsumsi air per unit rumah sakit (Lt/bed/ hari)

$\mathrm{q}(\mathrm{sp})=$ adalah konsumsi air per unit puskesmas (Lt/unit/hari) Sumber: SNI 19-6728.1-2002 Penyusunan Neraca Sumber Daya (2002)

\section{Kebutuhan Air Fasilitas Pendidikan}

Kebutuhan air untuk fasilitas pendidikan dihitung berdasarkan jumlah murid di DAS Bodri dengan asumsi bahwa terdapat 22 hari libur nasional, 29 hari libur semester, dan 48 hari libur mingguan (Kumalajati, dkk., 2015). Standar kebutuhan air untuk setiap murid adalah $10 \mathrm{Lt} /$ hari. Kebutuhan air sektor pendidikan dilakukan dengan menggunakan rumus persamaan (5).

$\mathrm{Qp}=\Sigma$ murid $\times \mathrm{q}(\mathrm{p}) / 1.000 \times(365-\Sigma$ hari libur $)$

Keterangan:

$\mathrm{Qp}=$ konsumsi air untuk fasilitas pendidikan ( $\mathrm{m}^{3} /$ tahun)

$\mathrm{q}(\mathrm{p})=$ standar konsumsi air tiap murid dengan satuan Lt/ murid/hari.

Sumber: SNI 19-6728.1-2002 Penyusunan Neraca Sumber Daya (2002)

Tabel 1. Standar Kebutuhan Air Untuk Masing-Masing Kebutuhan Air

\begin{tabular}{|c|c|c|}
\hline Jenis Kepentingan & Standar Kebutuhan & Satuan \\
\hline Domestik & 60 & Lt/kapita/hari \\
\hline $\begin{array}{l}\text { Kesehatan } \\
\text {-Puskesmas } \\
\text {-Rumahsakit } \\
\text { Pendidikan }\end{array}$ & $\begin{array}{c}2.000 \\
200 \\
10\end{array}$ & $\begin{array}{l}\text { Lt/unit/hari } \\
\text { Lt/bed/hari } \\
\text { Lt/murid/hari }\end{array}$ \\
\hline $\begin{array}{l}\text { Peribadatan } \\
\text {-Masjid } \\
\text {-Mushola } \\
\text { Perkantoran }\end{array}$ & $\begin{array}{c}3.000 \\
2.000 \\
10\end{array}$ & $\begin{array}{c}\text { Lt/unit/hari } \\
\text { Lt/unit/hari } \\
\text { Lt/pegawai/hari }\end{array}$ \\
\hline Industri & 500 & Lt/tenagakerja/hari \\
\hline Pertokoan & 10 & Lt/pegawaihari \\
\hline Pasar & 12.000 & Lt/hektar/hari \\
\hline Warung makan & 100 & Lt/tempat duduk/hari \\
\hline $\begin{array}{l}\text { Peternakan } \\
\text {-Sapi } \\
\text {-Domba/kambing } \\
\text {-Unggas } \\
\text { Irigasi }\end{array}$ & $\begin{array}{c}40 \\
5 \\
0,6 \\
1\end{array}$ & $\begin{array}{l}\text { Lt/ekor/hari } \\
\text { Lt/ekor/hari } \\
\text { Lt/ekor/hari } \\
\text { Lt/det/hektar }\end{array}$ \\
\hline Tambak & 4,91 & Lt/kapita/hari \\
\hline
\end{tabular}


Kebutuhan Air Fasilitas Peribadatan

Kebutuhan air untuk fasilitas peribadatan dihitung dengan menggunakan jumlah masjid dan mushola yang ditemukan di DAS Bodri. Standar kebutuhan air untuk tiap masjid adalah $3.000 \mathrm{Lt} /$ hari, sedangkan standar kebutuhan air untuk tiap mushola adalah $2.000 \mathrm{Lt} /$ hari. Kebutuhan air sektor fasilitas peribadatan dihitung dengan menggunakan rumus persamaan (6) sebagai berikut:

$\mathrm{Qib}($ mas $)=\Sigma$ masjid $\mathrm{x} 365$ hari $\mathrm{x} \mathrm{q}$ (ibmas) $/ 1.000$.

Dari persamaan (6) dapat dijabarkan lagi menjadi persamaan (7).

Qib(mus) $=\sum$ mushola $\times 365$ hari $\times$ q(ibmus) $/ 1.000$

Sehingga dapat di rumuskan secara sederhana sebagai persamaan (8)'

$\mathrm{Qib}=\mathrm{Qib}(\mathrm{mas})+\mathrm{Qib}(\mathrm{mus})$

\section{Keterangan:}

$\mathrm{Qib}=$ konsumsi air untuk fasilitas peribadatan ( $\mathrm{m}^{3} /$ tahun)

$\mathrm{Qib}$ (mas)= konsumsi air masjid ( $\mathrm{m}^{3} /$ tahun)

Qib(mus)= konsumsi air mushola ( $\mathrm{m}^{3} /$ tahun)

$\mathrm{q}(\mathrm{ibmas})=$ standar air masjid (Lt/unit/hari)

$\mathrm{q}(\mathrm{ibmus})=$ standar konsumsi air mushola (Lt/unit/hari).

Sumber: SNI 19-6728.1-2002 Penyusunan Neraca Sumber Daya (2002)

\section{Kebutuhan Air Perkantoran}

Kebutuhan air untuk perkantoran dihitung berdasarkan jumlah pegawai yang bekerja di kantor tersebut. Standar kebutuhan air untuk tiap pegawai kantor adalah $10 \mathrm{Lt} / \mathrm{hari}$. Rumus yang digunakan untuk menghitung kebutuhan air sektor perkantoran adalah persamaan (9).

$\mathrm{Qk}=\Sigma$ pegawai $\mathrm{x} \mathrm{q}(\mathrm{k}) / 1.000 \mathrm{x}(365-\Sigma$ hari libur $)$

\section{Keterangan:}

$\mathrm{Qk}=$ konsumsi air untuk fasilitas perkantoran ( $\mathrm{m}^{3} /$ tahun) $\mathrm{q}(\mathrm{k})=$ standar kebutuhan air fasilitas perkantoran (Lt/ pegawai/hari)

Sumber: SNI 19-6728.1-2002 Penyusunan Neraca Sumber Daya (2002)

\section{Kebutuhan Air Industri}

Kebutuhan air untuk industri dihitung berdasarkan jumlah tenaga kerja dimiliki oleh industri di DAS Bodri. Data jumlah tenaga kerja diperoleh dari publikasi BPS tahun 2011 - 2020. Kebutuhan air industri dihitung dengan menggunakan 6 hari kerja, dimana diasumsikan dalam setahun terdapat 48 hari libur mingguan dan 22 hari libur nasional (Kumalajati, dkk., 2015). Standar kebutuhan air untuk industri sebesar $10 \mathrm{Lt} /$ tenaga kerja/hari. Perhitungan kebutuhan air untuk industri dihitung dengan menggunakan rumus persamaan (10) .

Qid-ind $=(365-\Sigma$ hari libur $) \times \Sigma$ tenaga kerja industri $\mathrm{x} \mathrm{q}$ (id -ind)/1.000.

\section{Keterangan:}

Qid-ind = Kebutuhan air untuk industri ( $\mathrm{m}^{3} /$ tahun)

$\mathrm{q}(\mathrm{id}$-ind $)=$ Standar kebutuhan air tenaga kerja industri (Lt/ tenaga kerja/hari)

Sumber: SNI 19-6728.1-2002 Penyusunan Neraca Sumber Daya (2002)

\section{Kebutuhan Air Pertokoan dan Pasar}

Kebutuhan air untuk pertokoan dihitung dengan ber- dasarkan jumlah pegawai toko dan jumlah luas pasar. Standar kebutuhan air untuk tiap pegawai toko adalah sebanyak $10 \mathrm{Lt} / \mathrm{hari}$, dan untuk luas pasar adalah sebanyak $12.000 \mathrm{Lt} /$ hektar untuk tiap harinya. Kebutuhan air sektor dasilitas pertokoan dihitung dengan menggunakan rumus persamaaan (11) dan (12).

Qid-psr $=365$ hari $\mathrm{x}$ luas pasar $\mathrm{x} \mathrm{q}(\mathrm{idpsr}) / 1.000$

Qid-toko $=365$ hari $x \Sigma$ pegawai $x \mathrm{q}($ idtoko $) / 1.000$.

\section{Keterangan:}

Qid-psr= konsumsi air untuk pasar ( $\mathrm{m}^{3} /$ tahun)

Qidtoko= konsumsi air untuk toko $\left(\mathrm{m}^{3} /\right.$ tahun)

$\mathrm{q}$ (id-toko)= standar konsumsi air toko (Lt/hari)

q (id-psr) = standar konsumsi air pasar (Lt/hektar/hari)

Sumber: SNI 19-6728.1-2002 Penyusunan Neraca Sumber Daya (2002)

\section{Kebutuhan Air Warung Makan}

Kebutuhan air untuk warung makan dihitung dengan berdasarkan jumlah tempat duduk yang disediakan oleh warung makan. Standar kebutuhan air untuk tiap tempat duduk adalah sebesar $100 \mathrm{Lt} / \mathrm{hari}$. Rumus yang digunakan untuk menghitung kebutuhan air sektor warung makan adalah dengan persamaan (13) .

Qid-wm $=365$ hari $x \Sigma$ kursi $x$ q $($ idwm $) / 1.000$

\section{Keterangan:}

Qid-wm= konsumsi air untuk warung makan ( $\mathrm{m}^{3} /$ tahun) q (id-wm)=standar konsumsi air warung makan (Lt/kursi/ hari)

Sumber: SNI 19-6728.1-2002 Penyusunan Neraca Sumber Daya (2002)

\section{Kebutuhan Air Peternakan}

Kebutuhan air untuk peternakan dihitung dengan menggunakan jumlah ternak yang dibagi menjadi beberapa kategori yakni sapi dan kerbau, domba dan kambing, babi, serta unggas. Standar kebutuhan air yang diperlukan sapi dan kerbau adalah $40 \mathrm{Lt} / \mathrm{ekor} / \mathrm{hari}$, untuk domba dan kambing adalah $5 \mathrm{Lt} /$ ekor/hari, untuk babi sebesar $6 \mathrm{Lt} / \mathrm{ekor} / \mathrm{hari}$, dan untuk unggas sebesar $0.6 \mathrm{Lt} / \mathrm{ekor} /$ hari. Kebutuhan air sektor peternakan dihitung dengan menggunakan rumus persamaan (14).

Qpt $=365$ hari $x\{q(c / b) \times P(c / b)+q(s / g) \times P(s / g)+q(p i) \times P(p i)+$ $\mathrm{q}(\mathrm{po}) \mathrm{xP}(\mathrm{po})\}$

\section{Keterangan:}

$\mathrm{Qpt}=$ konsumsi air untuk ternak ( $\mathrm{m}^{3} /$ tahun)

$\mathrm{q}(\mathrm{c} / \mathrm{b})=$ standar konsumsi air sapi/kerbau (Lt/ekor/hari)

$\mathrm{P}(\mathrm{c} / \mathrm{b})=$ jumlah sapi/kerbau (ekor)

$\mathrm{q}(\mathrm{s} / \mathrm{g})=$ standar konsumsi air domba/kambing (Lt/ekor/hari)

$\mathrm{P}(\mathrm{s} / \mathrm{g})=$ jumlah domba/kambing (ekor)

$\mathrm{q}(\mathrm{pi})=$ standar konsumsi air babi (Lt/ekor/hari)

$\mathrm{P}(\mathrm{pi})=$ jumlah babi (ekor)

$\mathrm{q}(\mathrm{po})=$ standar konsumsi air unggas (Lt/ekor/hari)

$\mathrm{P}(\mathrm{po})=$ jumlah unggas (ekor).

Sumber: SNI 19-6728.1-2002 Penyusunan Neraca Sumber Daya (2002)

\section{Kebutuhan Air Irigasi}

Kebutuhan air untuk irigasi dihitung dengan menggunakan luas lahan irigasi. Standar kebutuhan air untuk lahan irigasi adalah sebanyak 1 Lt/detik untuk tiap 
harinya. Kebutuhan air untuk sektor irigasi dihitung dengan menggunakan rumus persamaan (15) .

Qi $=A x(q(i) / 1.000) \times \operatorname{Tn} \times(3.600 \times 24)$

Keterangan:

$\mathrm{Q} \mathrm{i}=$ konsumsi kebutuhan air untuk irigasi ( $\mathrm{m}^{3} /$ tahun)

$\mathrm{q}(\mathrm{i})=$ standar konsumsi air untuk irigasi sebanyak $1 \mathrm{Lt} / \mathrm{detik}$ untuk tiap hektarnya (liter/detik/ha)

$\mathrm{Tn}=$ jumlah hari irigasi. Digunakan asumsi irigasi selama 4 bulan dalam setahun.

Sumber: SNI 19-6728.1-2002 Penyusunan Neraca Sumber Daya (2002)

\section{Kebutuhan Air Tambak}

Kebutuhan air tambak dihitung berdasarkan luas tambak yang terdapat di DAS Bodri. Standar konsumsi air untuk tambak sebesar $4.910 \mathrm{Lt} / \mathrm{ha} / \mathrm{h}$ ari, dengan rumus perhitungan kebutuhan air tambak dengan persamaan (16).

$\mathrm{Q}(\mathrm{FP})=365 \mathrm{x}(\mathrm{g}(\mathrm{t})) / 1.000 \mathrm{x} \mathrm{q}(\mathrm{f}) \mathrm{x} \mathrm{A}(\mathrm{FP}) \times 1.000$

Keterangan:

$\mathrm{Q}(\mathrm{FP})=$ Kebutuhan air untuk tambak ( $\mathrm{m}^{3} /$ tahun)

$\mathrm{g}(\mathrm{t})=$ Standar konsumsi air untuk tambak (Lt/ha/hari)

$\mathrm{q}(\mathrm{f})=$ Kebutuhan air flushy $(7 \mathrm{~mm} /$ tahun $)$

$\mathrm{A}(\mathrm{FP})=$ Luas tambak $(\mathrm{ha})$

Sumber: SNI 19-6728.1-2002 Penyusunan Neraca Sumber Daya (2002)

\section{Ketersediaan Air Permukaan}

Ketersediaan air permukaan di DAS Bodri diperoleh dari data sekunder berupa data debit setengah bulanan Sungai Bodri tahun 2005 - 2020. Pengukuran debit dilakukan oleh Balai Pengelola Sumber Daya Air (BPSDA) Bodri Kuto, dimana pengamatan dilakukan di Bendung Juwero yang merupakan debit akumulasi dari Sungai Bodri dan irigasi. Debit pengukuran kemudian diolah kembali untuk menghasilkan debit tahunan DAS Bodri. Potensi ketersediaan air permukaanuntuk tahun 2010-2019 dilihat dari data historis.

Ketersediaan air permukaan pada tahun 2040 diperoleh dengan menggunakan debit andalan berdasarkan data tahun 2010 - 2019. Debit andalan dihitung menggunakan metode kurva durasi debit sesuai dengan SNI 6738:2015 Tentang Perhitungan Debit Andalan Sungai dengan Kurva Durasi Debit. Penentuan debit andalan menggunakan metode tersebut dilakukan dengan cara mengolah data debit setengah bulanan menjadi data debit tahunan, engurutkan data debit tahunan dari besar ke kecil dan menentukan peringkat data.

Menghitung probabilitas setiap data dengan menggunakan perhitungan probabilitas Weibull menggunakan persamaan (17).

$\mathrm{P}(\mathrm{X} \geq \mathrm{x})=\mathrm{mn}+1.100 \%$.

Keterangan:

$\mathrm{P}(\mathrm{X} \geq \mathrm{x})$ : Probabilitas terjadinya debit $(\mathrm{X})$ yang lebih besar atau sama dengan $\mathrm{x} \mathrm{m} / \mathrm{s}$

m : Peringkat data

n : Jumlah data

$\mathrm{X} \quad$ : Data debit

$\mathrm{x} \quad$ : Debit andalan yang sesuai dengan peruntukannya

Menghitung debit andalan berdasarkan probabilitas sesuai dengan peruntukannya, membuat kurva durasi debit dengan data dari poin 3 dan 4
Proyeksi Jumlah Kebutuhan Air

Besar kecilnya kebutuhan air dihitung berdasarkan jumlah parameter pada masing-masing perhitungan. Proyeksi jumlah untuk menghitung ketersediaan air permukaan dilakukan secara eksponensial dan tetap. Hal ini bergantung kepada jumlah dan jenis data. Rumus secara eksponensial dilakukan untuk menghitung besarnya jumlah penduduk, Bed Rumah Sakit, unit puskesmas, murid, tempat ibadah, jumlah toko, tempat duduk rumah makan, luas perkebunan, luas sawah, jumlah unggas, jumlah sapi dan kerbau, jumlah babi, jumlah pegawai, dan jumlah tenaga industri. Penggunaan rumus secara eksponensial untuk melakukan proyeksi ini dilatarbelakangi oleh penduduk sebagai konsumen ketersediaan air dan jumlah penduduk yang terus bertambah secara eksponensial. Pertumbuhan penduduk secara eksponensial menunjukkan bahwa jumlah penduduk terus mengalami pertumbuhan secara terus menerus dengan angka pertumbuhan (rate) yang kosntan (Afrianto, 2015). Data lain, jumlah bed rumah sakit, luas pasar, dan tambak dihitung dengan asumsi tetap karena keterbatasan data yang hanya ditemukan dalam satu tahun.

Kesetimbangan Kebutuhan dan Ketersediaan Air Permukaan

Analisis neraca air dilakukan dengan membandingkan kebutuhan air dan ketersediaan air permukaan selama periode 2010-2019. Neraca air divisualisasikan dengan diagram untuk memudahkan identifikasi apakah DAS mengalami surplus atau defisit air secara kuantitas. Selanjutnya analisis tersebut digabungkan dengan proyeksi kebutuhan air untuk melihat kelestarian air secara kuantitas. Kesetimbangan air pada tahun 2040 dilihat dari data proyeksi kebutuhan air tahun 2040 dan data ketersediaan air permukaan menggunakan debit andalan.

\section{HASIL DAN PEMBAHASAN}

\section{Kebutuhan Air}

Pemanfaatan air oleh penduduk di DAS Bodri dapat dikategorikan menjadi dua yaitu untuk kegiatan rumah tangga (domestik) dan aktivitas sosial-ekonomi (non domestik). Kebutuhan air domestik dipengaruhi oleh faktor jumlah penduduk sedangkan kebutuhan air non domestik ditentukan oleh jenis aktivitas sosial ekonomi. Analisis kebutuhan air di DAS Bodri mencakup periode 2010-2019 dan proyeksi kebutuhan air untuk periode 2020-2040.

Estimasi kebutuhan air domestik di DAS Bodri dilakukan berdasarkan data jumlah penduduk tahun 2010-2019 dan hasil perhitungan proyeksi penduduk untuk tahun 20202040. Populasi penduduk di DAS Bodri pada periode 20102019 mengalami pertumbuhan dengan tingkat pertumbuhan penduduk rata-rata setiap tahunnya sebesar 0,004 (Tabel 2). Hal tersebut menunjukkan bahwa pertumbuhan penduduk di DAS Bodri tergolong ke pertumbuhan positif sehingga populasi penduduk diproyeksikan terus bertambah hingga tahun 2040. Pada 4 tahun pertama (2010-2013), jumlah penduduk di DAS Bodri mengalami fluktuasi sehingga menyebabkan kebutuhan air domestik pada periode tersebut berubah-ubah antara 21-21,06 juta $\mathrm{m}^{3}$ (Gambar 5). Selain itu, kebutuhan air domestik setelah tahun 2013 mengalami peningkatan dan diproyeksikan volume air yang dibutuhkan penduduk untuk aktivitas domestik mencapai 24,4 juta $\mathrm{m}^{3}$ pada akhir tahun proyeksi (Gambar 5). Dengan demikian, peningkatan jumlah penduduk diiringi oleh kenaikan kebu- 
tuhan air domestik (Kumalajati dkk., 2015)

Kebutuhan air non domestik di DAS Bodri lebih banyak dibandingkan kebutuhan air domestik. Hal tersebut disebabkan oleh permintaan kebutuhan dari berbagai sektor kegiatan yang terdapat di DAS Bodri, meliputi fasilitas publik, sektor komersial, dan sektor agrikultur. Berdasarkan Gambar 5, kebutuhan air non domestik tahun 2010-2019 berada di kisaran 8.000-8.900 juta $\mathrm{m}^{3}$. Kebutuhan air pada periode tersebut mengalami tren fluktuatif tetapi secara keseluruhan, kebutuhan air cenderung meningkat dengan rasio rata-rata sebesar 0,0029. Dengan rasio yang bernilai positif maka kebutuhan air non domestik diproyeksikan akan terus meningkat hingga tahun 2040. Pada tahun 2040, kebutuhan air non domestik diestimasikan mencapai kurang lebih 9.700 juta $\mathrm{m}^{3}$. Kebutuhan air non domestik tersebut dipengaruhi oleh berbagai sektor kegiatan yang diklasifikasikan menjadi kebutuhan air untuk fasilitas publik, komersial, dan agrikultur.

Kebutuhan air untuk fasilitas kesehatan merupakan akumulasi kebutuhan air pada unit puskesmas dan rumah sakit. Kebutuhan tersebut ditentukan oleh jumlah unit puskesmas dan unit tempat tidur yang tersedia pada rumah sakit yang ada di wilayah DAS Bodri. Wilayah DAS Bodri dilengkapi fasilitas kesehatan yang meliputi sebanyak 200 unit tempat tidur pada rumah sakit dan 56-61 unit puskesmas. Total unit puskesmas dan kuantitas tempat tidur rumah sakit relatif konstan dari tahun ke tahun sehingga penambahan kebutuhan air tidak signifikan. Berdasarkan Gambar 6, dapat diketahui bahwa total kebutuhan air untuk fasilitas kesehatan berada pada rentang 150.000-151.000 $\mathrm{m}^{3}$ selama periode 2010-2040.

Kebutuhan air untuk fasilitas pendidikan dipengaruhi oleh pertumbuhan penduduk dan angka partisipasi dalam pendidikan atau jumlah murid. Jumlah murid sebagai faktor penghitung kebutuhan ini diproyeksikan menggunakan rasio perhitungan geometri. Berdasarkan Gambar 6, kebutuhan air untuk fasilitas pendidikan cenderung menurun menurun. Hal ini dapat disebabkan oleh menurunnya angka partisipasi dalam pendidikan.

Kebutuhan air untuk fasilitas peribadatan merupakan akumulasi kebutuhan air dari fasilitas peribadatan yakni mas-

Tabel 2. Rasio Pertumbuhan Penduduk DAS Bodri 2010-2019

\begin{tabular}{ccc}
\hline Tahun & Jumlah Penduduk & Rasio \\
\hline 2010 & 592.035 & $-0,026$ \\
2011 & 576.901 & 0,022 \\
2012 & 589.754 & $-0,022$ \\
2013 & 576.580 & 0,005 \\
2014 & 579.542 & 0,003 \\
2015 & 581.008 & 0,006 \\
2016 & 584.226 & 0,012 \\
2017 & 591.029 & 0,011 \\
2018 & 597.330 & 0,027 \\
2019 & 613.256 & 0,004 \\
Rasio Pertumbuhan Penduduk Rata-Rata & 0,0042
\end{tabular}

Sumber: BPS Kabupaten Kendal, Kabupaten Semarang, Kabupaten Temanggung, dan Kabupaten Wonosobo Dalam Angka 2011-2020 (diolah) jid dan mushola. Kebutuhan air tersebut ditentukan dari jumlah kebutuhan air masing-masing masjid dan mushola untuk kegiatan peribadatan yang ada di wilayah DAS Bodri. Berdasarkan publikasi BPS, jumlah unit masjid dan mushola di tahun 2010 yakni 760 unit masjid dan 1280 unit mushola dan di tahun 2019 menjadi 766 unit masjid dan 1280 unit mushola. Berdasarkan data tersebut didapatkan proyeksi jumlah unit fasilitas peribadatan sampai tahun 2040 yang mana terjadi penambahan unit fasilitas peribadatan sebanyak satu unit baik masjid dan mushola selama 3 tahun sekali. Peningkatan jumlah fasilitas peribadatan ini sejalan bertambahnya jumlah penduduk yang ada di wilayah DAS Bodri dari tahun ke tahun yang mana tentunya membutuhkan adanya peningkatan jumlah fasilitas penunjang yang ada, salah satunya yakni fasilitas peribadatan.

Berdasarkan jumlah dan proyeksi fasilitas peribadatan yang ada di wilayah DAS Bodri didapatkan nilai jumlah dan proyeksi kebutuhan air untuk fasilitas peribadatan di wilayah DAS Bodri. Mengikuti tren jumlah fasilitas peribadatan yang ada yang selalu mengalami peningkatan dari tahun ke tahun, jumlah kebutuhan air juga sejalan dengan hal tersebut. Berdasarkan Gambar 6 dapat diketahui jumlah kebutuhan air untuk fasilitas peribadatan di wilayah DAS Bodri dari periode tahun 2010-2040 yang mana jumlah kebutuhan air berada di rentang 1.766.600-1.785.945 $\mathrm{m}^{3}$. Jumlah kebutuhan

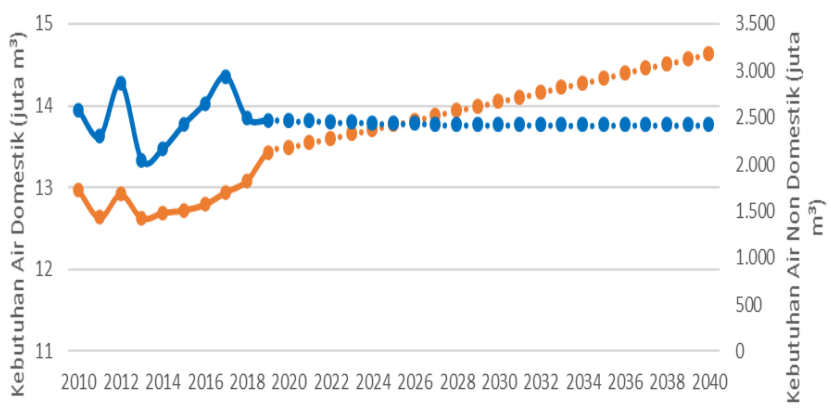

Tahun

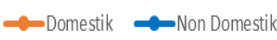

Gambar 5. Grafik Kebutuhan Air untuk Keperluan Domestik dan Non-Domestik di DAS Bodri Tahun 2010-2040

Sumber: Data Kebutuhan Air di DAS Bodri Tahun 2010-2040 (diolah)

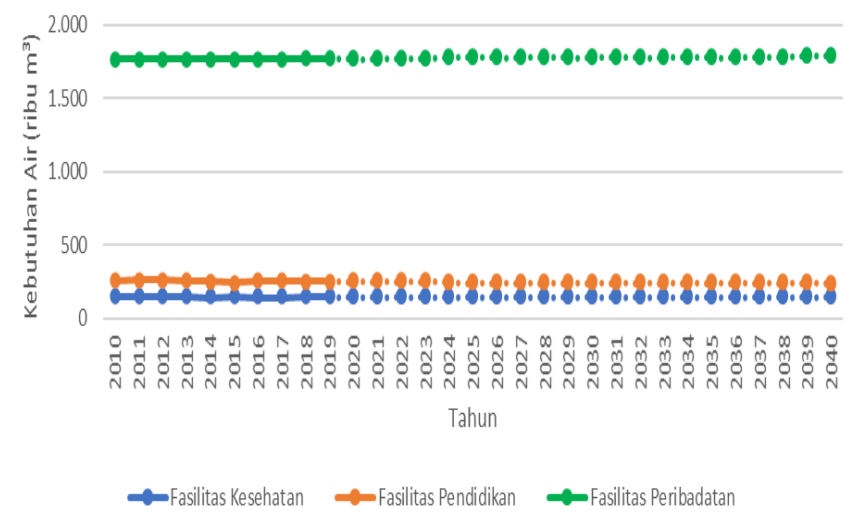

Gambar 6. Grafik Kebutuhan Air Fasilitas Publik di DAS Bodri Tahun 2010-2040

Sumber: Data Kebutuhan Air di DAS Bodri Tahun 20102040 (diolah) 
air untuk fasilitas peribadatan di wilayah DAS Bodri ini cukup tinggi bila dibandingkan dengan jumlah kebutuhan air untuk fasilitas pendidikan dan kesehatan. Hal ini terjadi karena jumlah fasilitas peribadatan yang jauh lebih banyak daripada jumlah fasilitas pendidikan maupun kesehatan di wilayah tersebut yang mana akan berakibat kepada jumlah kebutuhan air yang lebih tinggi.

Kebutuhan air untuk perkantoran dilakukan perhitungan dengan mengalikan jumlah penduduk dengan standar konsumsi air dan jumlah hari kerja dalam satu tahun. Kebutuhan air untuk perkantoran masuk kedalam kebutuhan non domestik. Kebutuhan non domestik terbagi menjadi dua yaitu kebutuhan institusional dan komersial. Untuk kebutuhan air secara institusional terdiri dari pemenuhan kebutuhan untuk perkantoran dan sekolah. Sedangkan untuk kebutuhan non domestik komersial atau industri terdiri dari kegiatan hotel, pasar, pertokoan, restoran dan industri (Wahyuni dan Junianto, 2017).

Dilihat dari data jumlah pegawai dalam satu DAS Bodri yang mencangkup empat Kabupaten yaitu Kabupaten Kendal, Kabupaten Temanggung, Kabupaten Wonosobo dan Kabupaten Semarang pada umumnya selalu meningkat jumlah pegawainya. Namun, ada pula yang mengalami penurunan yaitu pada tahun 2015 hingga tahun 2017 dan naik kembali pada tahun 2018. Hal ini tentunya akan berpengaruh pada besarnya kebutuhan air pada sektor perkantoran. Nilai kebutuhan air untuk perkantoran pada tahun 2010 hingga tahun 2040 berkisar antara $22.311,51 \mathrm{~m}^{3}$ hingga $319.620,3 \mathrm{~m}^{3}$ (Gambar 7). Peningkatan kebutuhan air sangat signifikan yang terjadi mulai dari tahun 2020 hingga tahun 2040.

Perkembangan industri di daerah utara Jawa sangat pesat. Hilir dari DAS Bodri berada pada Kabupaten Kendal dan berada di daerah utara Jawa. Kebutuhan air untuk industri di DAS Bodri besar. Hal ini dipengaruhi oleh industri yang berada di DAS Bodri yang termasuk ke dalam Kabupaten Kendal sangat banyak. Kebutuhan air industri dapat diketahui melalui jumlah tenaga kerja. Jumlah tenaga kerja industri dari tahun 2010 hingga tahun 2019 cenderung meningkat. Peningkatan ini mempengaruhi proyeksi tenaga kerja untuk tahun 2020 hingga 2040 terus meningkat. Peningkatan jumlah tenaga kerja ini sebanding dengan kebutuhan air. Kebutuhan air industri di DAS Bodri terus meningkat.

Kebutuhan air untuk pertokoan dibagi menjadi dua sektor yaitu pasar dan pertokoan. Kebutuhan air untuk pasar didasarkan pada luas pasar yang terdapat di DAS Bodri, dimana data didapatkan dari Dinas Perdagangan Kabupaten Kendal dengan standar kebutuhan air sebesar $12000 \mathrm{Lt} /$ hektar/hari. Sementara itu, kebutuhan air pertokoan didasarkan pada jumlah karyawan yang bekerja di toko. Data jumlah karyawan toko diperoleh dengan asumsi bahwa setiap toko memiliki dua orang karyawan dengan standar kebutuhan air sebesar 10 Lt/pegawai/hari (Kumalajati, dkk., 2015).

Berdasarkan data luas pasar dari Dinas Perdagangan diketahui bahwa luas pasar di DAS Bodri tidak mengalami perubahan luas dari tahun 2010 - 2019, sehingga proyeksi luas pasar untuk tahun berikutnya tidak mengalami perubahan. Oleh karena itu, kebutuhan air untuk pasar setiap tahun tidak mengalami perubahan yaitu sebesar $24.535,45$ $\mathrm{m}^{3} /$ tahun (Gambar 7). Kebutuhan air pasar digunakan sebagai penunjang dalam memenuhi kebutuhan air sebagai penunjang kegiatan jual beli.

Kebutuhan air untuk pertokoan di DAS Bodri tidak men- galami peningkatan dari tahun ke tahun, sehingga proyeksi kebutuhan air pertokoan juga tidak mengalami peningkatan. Berdasarkan perhitungan kebutuhan air pertokoan dengan asumsi bahwa setiap toko memiliki dua orang pegawai maka diketahui kebutuhan air pertokoan di DAS Bodri sebesar $35.587,50 \mathrm{~m}^{3} /$ tahun (Gambar 7). Kebutuhan air pertokoan lebih besar dibandingkan dengan kebutuhan air pasar, karena jumlah pasar atau luas pasar lebih sedikit dibandingkan jumlah toko. Hal tersebut dikarenakan jumlah pasar yang menjadi standar pelayanan umum untuk permukiman minimal satu unit pasar untuk setiap 30.000 penduduk (Salim, 2019). Sementara itu, jumlah toko tidak memiliki standar yang berarti jumlah dan keberadaannya tidak terbatas.

Dewasa ini, perkembangan pasar dalam jaringan (ecommerce) terus berkembang. E-commerce dapat membuka pasar yang lebih luas dan membuka peluang bisnis baru serta memberikan kemudahan bagi konsumen untuk melakukan transaksi jual beli secara efisien, mudah, dan efektif (Azizah, dkk, 2019). Kemudahan tersebut tidak menutup kemungkinan bahwa pasar dan pertokoan akan lebih berkembang secara online, sehingga perkembangan pasar dan toko secara langsung bisa saja menjadi lambat bahkan terhenti di kemudian hari. Meskipun demikian, kebutuhan air yang tidak mengalami peningkatan dikhawatirkan akan terjadi kekurangan air bersih untuk memenuhi kebutuhan air di waktu yang akan datang seperti pada halnya kebutuhan air untuk pasar dan pertokoan.

Kebutuhan air untuk warung makan di DAS Bodri didasarkan pada jumlah rumah makan, warung makan dan restoran yang terdapat di wilayah tersebut. Data jumlah warung makan kemudian dikalikan dengan angka rata-rata jumlah kursi warung makan untuk wilayah Jawa Tengah yang diperoleh dari publikasi Statistik Restoran dan Rumah Makan, serta Statistik Penyediaan Makanan dan Minuman yang diterbitkan oleh BPS. Definisi warung makan, rumah makan dan restoran menurut BPS (2020) adalah usaha penyediaan makanan dan minuman dengan skala menengah besar, dan memiliki penghasilan di atas 2,5 miliar rupiah atau bekerja di bawah perseroan terbatas (PT).

Jumlah kebutuhan air untuk sektor warung makan mengalami peningkatan yang fluktuatif antara tahun 2010 hingga tahun 2019. Perubahan ini disebabkan jumlah warung makan yang berubah (karena ada tutup usaha dan membuka usaha baru) dan jumlah rata-rata kursi yang disediakan rumah makan, yang mengalami perubahan jumlah dari tahun ke tahun. Kebutuhan air tahun 2020 hingga 2040 dikalkulasikan

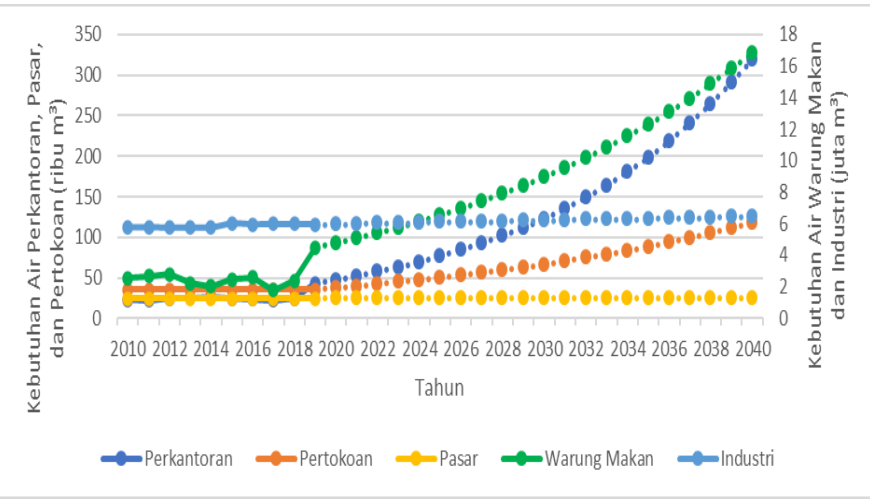

Gambar 7. Grafik Kebutuhan Air Sektor Komersial di DAS Bodri Tahun 2010-2040

Sumber: Data Kebutuhan Air di DAS Bodri Tahun 2010-2040 (diolah) 
dengan menggunakan proyeksi, sehingga menghasilkan peningkatan yang konstan dari tahun ke tahun. Puncak kebutuhan air pada tahun 2040 mencapai angka 16.840.136,39 $\mathrm{m}^{3}$ (Gambar 7).

Kebutuhan air untuk peternakan adalah kebutuhan air untuk pembudidayaan hewan ternak. Jenis ternak yang dikembangbiakkan di wilayah DAS Bodri adalah unggas, sapi/kerbau/kuda, kambing/domba/kelinci, dan babi. Kebutuhan air untuk peternakan ditentukan berdasarkan jumlah ternak dan standar kebutuhan air ternak. Jenis ternak yang berbeda mempunyai standar kebutuhan air yang berbeda pula.

Jumlah ternak di DAS Bodri pada tahun 2010-2019 mengalami pertumbuhan dengan pertumbuhan rata-rata sebesar 0,007 untuk unggas, 0,001 untuk sapi/kerbau/kuda, -0,036 untuk kambing/domba/kelinci, sedangkan untuk pertumbuhan babi diasumsikan tetap karena data jumlah babi yang hampir tidak berubah dari tahun ke tahun. Berdasarkan Gambar 8, dapat diketahui bahwa total kebutuhan air untuk peternakan tahun 2010-2040 berada pada rentang 1.8802.780 juta $\mathrm{m}^{3}$. Penurunan kebutuhan air yang signifikan terjadi pada tahun 2013 dan peningkatan kebutuhan air yang signifikan terjadi pada tahun 2017. Sementara itu, untuk hasil proyeksi kebutuhan air peternakan tahun 2020-2040 mengalami penurunan yang tidak signifikan setiap tahunnya. Total kebutuhan ini merupakan kebutuhan air paling banyak dibandingkan dengan kebutuhan lainnya.

Kebutuhan air untuk irigasi di DAS Bodri dipengaruhi oleh luasnya sawah yang berada di daerah tersebut dan masa irigasi. Jumlah hari irigasi di daerah ini diasumsikan setiap empat bulan. Luas sawah di DAS Bodri cenderung meningkat, tetapi tidak signifikan. Kecenderungan peningkatan tersebut juga menyebabkan proyeksi luas sawah juga meningkat. Peningkatan luas sawah tersebut dapat disebabkan karena alih fungsi lahan menjadi lahan pertanian disamping sebagai lahan terbangun. Peningkatan luas sawah juga menyebabkan kebutuhan air untuk irigasi juga meningkat. Peningkatan kebutuhan air tersebut tidak begitu signifikan seperti pada Gambar 8. Standar kebutuhan air untuk irigasi tersebut adalah $1 \mathrm{Lt} /$ detik untuk setiap hektarnya.

Kebutuhan air untuk tambak adalah kebutuhan air yang digunakan dalam kegiatan pembudidayaan perikanan di wilayah DAS Bodri. Jumlah kebutuhan air untuk tambak dipengaruhi oleh total luas (Ha) tambak yang ada di wilayah DAS Bodri. Seperti diketahui tambak di wilayah DAS Bodri sebagian besar berada di dekat pesisir pantai utara Jawa yang mana memang cocok digunakan sebagai kegiatan budidaya perikanan. Berdasarkan data yang diperoleh di wilayah DAS Bodri diketahui memiliki luas tambak sebesar $1.458 \mathrm{Ha}$. Luas tambak tersebut selalu konstan dari tahun ke tahun dan ditengarai tidak mengalami penambahan yang signifikan. Hal ini dapat terjadi dikarenakan daerah pesisir yang relatif padat yang mana luas lahan yang ada sudah terisi oleh penggunaan yang bermacam-macam baik untuk permukiman, komersial, maupun kegiatan industri sehingga tidak terdapat lagi lahan kosong guna melakukan pembukaan lahan tambak baru lagi.

Perhitungan kebutuhan air untuk kebutuhan tambak di wilayah DAS Bodri diperoleh dari luas lahan tambak yang ada dikalikan dengan rumus dan variabel standar kebutuhan air guna kebutuhan perikanan. Berdasarkan Pedoman Teknis Bidang Air Bersih, Direktorat Air Bersih, Direktorat Jenderal Cipta Karya (Dinas Pekerjaan Umum, 1996) diperoleh nilai standar terpilih untuk kegiatan perikanan tambak sebesar

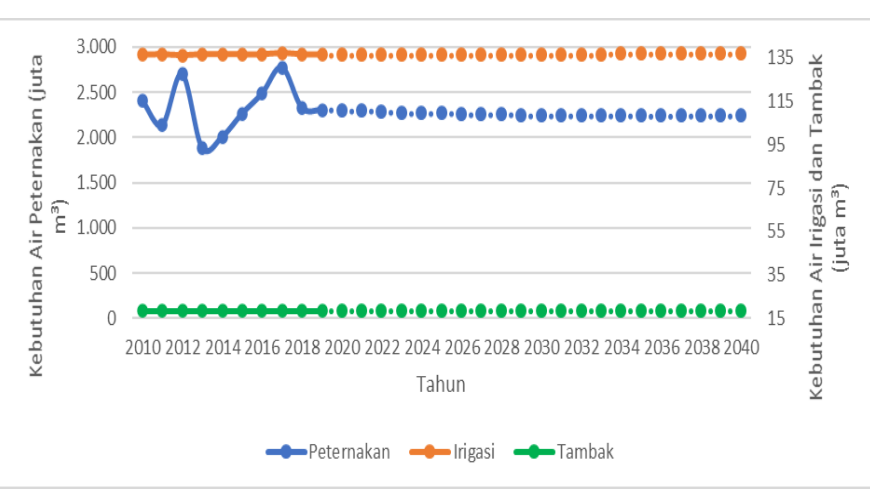

Gambar 8. Grafik Kebutuhan Air Sektor Agrikultur di DAS Bodri Tahun 2010-2040

Sumber: Data Kebutuhan Air di DAS Bodri Tahun 2010-2040 (diolah)

4,91 Lt/hari. Berdasarkan hasil perhitungan diperoleh jumlah kebutuhan air untuk kegiatan perikanan tambak sebesar $18.292 .931 \mathrm{~m}^{3}$. Jumlah tersebut relatif konstan dari tahun ke tahun bahkan sampai proyeksi untuk tahun 2040.

Kebutuhan air domestik dan non domestik mempengaruhi kebutuhan air total di DAS Bodri. Berdasarkan Gambar 9, kebutuhan air total di DAS Bodri pada periode 2010-2019 hasil penjumlahan kebutuhan air domestik dan non-domestik mengalami tren yang cenderung meningkat meskipun fluktuatif variasinya. Kebutuhan air total tersebut diestimasikan terus meningkat hingga tahun 2040. Kebutuhan air pada tahun 2040 sebesar 2.435.065.691,97 $\mathrm{m}^{3}$. Faktor stimulan utama peningkatan kebutuhan air di wilayah DAS Bodri salah satunya adalah eksistensi Kabupaten Kendal dalam kawasan pertumbuhan ekonomi koridor KendalSemarang-Demak. Lokasi Kabupaten Kendal yang strategis di koridor tersebut mendorong akselerasi restrukturisasi Kabupaten Kendal yang ditandai oleh perubahan penggunaan lahan untuk fungsi permukiman dan kawasan industri (Wilonoyudho, 2010). Menurut temuan Altarans dan Pradoto (2018), wilayah perkotaan Kendal sendiri telah mengalami perubahan penggunaan lahan dengan rasio berkisar antara 0,45-0,87. Dengan demikian, peningkatan kebutuhan air untuk tahun-tahun kedepannya perlu menjadi perhatian dalam pemenuhannya mengingat ketersediaan air permukaan yang cenderung tetap dan air di DAS Bodri digunakan untuk keempat kabupaten yang wilayahnya saling berbatasan (Kabupaten Kendal, Kabupaten Wonosobo, Kabupaten Temanggung, dan Kabupaten Semarang).

\section{Ketersediaan Air Permukaan}

Ketersediaan air permukaan DAS Bodri merupakan air permukaan dari pengukuran debit di outlet pada sungai Bodri. Akumulasi debit total dalam setiap tahunnya ditunjukkan pada Gambar 10. Debit dari tahun 2010-2019 mengalami fluktuasi yang ditunjukkan oleh naik dan turunnya besarnya debit. Ketersediaan air permukaan DAS Bodri memiliki angka tertinggi pada tahun 2010 sebesar $1.270 .884 .38 \mathrm{~m}^{3} /$ tahun. Ketersediaan air permukaan terendah terjadi pada tahun 2015 yaitu sebesar $757.137 .889 \mathrm{~m}^{3} /$ tahun. Ketersediaan air permukaan DAS Bodri yang mengalami fluktuasi dari tahun ketahun dapat dipengaruhi oleh kondisi limpasan. Besar kecilnya limpasan dipengaruhi oleh beberapa faktor, yaitu faktor meteorologi, faktor DAS, dan faktor manusia (Seyhan, 1977 dalam Setyowati, 2010). Menurut Asdak (2007), adanya 


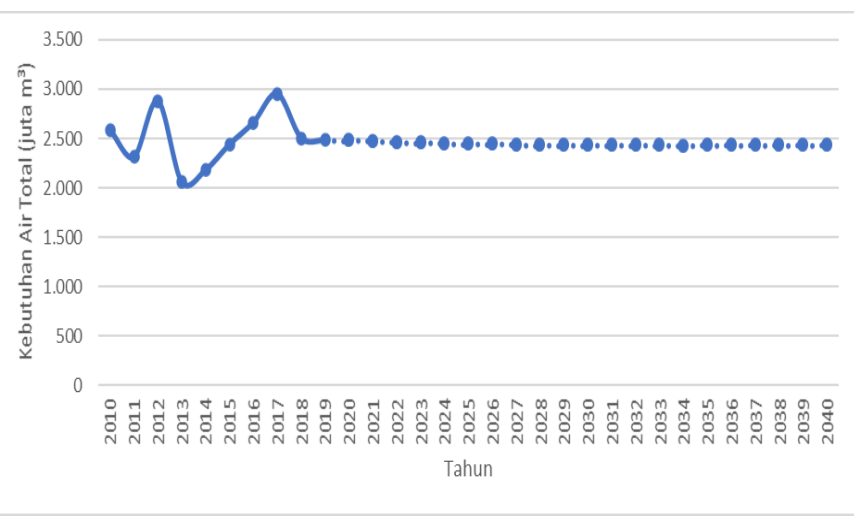

Gambar 9. Grafik Kebutuhan Air Total di DAS Bodri Tahun 2010-2040

Sumber: Data Kebutuhan Air di DAS Bodri

Tahun 2010-2040 (diolah)

perubahan penggunaan lahan dan vegetasi dalam skala besar dapat mempengaruhi hasil air.

Debit sungai selalu bervariasi dalam periode waktu tertentu. Variasi debit sungai berpengaruh terhadap ketersediaan air permukaan setiap tahunnya. Diagram yang umum digunakan dalam mempelajari variabilitas debit sungai yaitu melalui kurva durasi aliran. Kurva durasi aliran menunjukkan hubungan antara debit sungai terhadap persentase probabilitas debit sungai tersebut dapat disamai atau dilampaui (Subramanya, 2008). Probabilitas debit sungai tertentu digunakan sebagai debit andalan dalam perencanaan pemenuhan kebutuhan air. Menurut Soemarto (1987) dalam Hanafi \& Yosananto (2018), debit andalan adalah besarnya debit yang tersedia dalam rangka pemenuhan kebutuhan air dengan mempertimbangkan estimasi risiko kegagalan. Penentuan debit andalan dilakukan dengan tujuan untuk mendapatkan nilai debit yang digunakan sebagai patokan dalam pemenuhan kebutuhan air.

Penentuan ketersediaan air permukaan di DAS Bodri pada tahun 2040 berdasarkan kurva durasi aliran (Gambar 11) yang diperoleh dari data debit Sungai Bodri tahun 20102019. Debit andalan yang dijadikan sebagai patokan yaitu Q80 atau debit probabilitas $80 \%$. Q80 berarti debit sungai yang terjadi diestimasikan sama atau lebih besar dari besaran debit pada probabilitas 80\% (Pusdiklat SDA \& Konstruksi, 2017). Perhitungan debit andalan $80 \%$ dengan metode probabilitas Weibull pada aliran Sungai Bodri menunjukkan nilai sebesar 810.497.236,10 m³ (Gambar 11). Dengan demikian, ketersediaan air permukaan DAS Bodri yang direncanakan untuk pemenuhan kebutuhan air di tahun 2040 sama dengan atau lebih dari 810.497.236,10 $\mathrm{m}^{3}$.

Kesetimbangan Kebutuhan dan Ketersediaan Air Permukaan

Analisis kesetimbangan air atau neraca air adalah analisis keseimbangan antara ketersediaan air permukaan dengan kebutuhan air di suatu DAS pada periode waktu tertentu (Anna dkk., 2016). Dengan penerapan neraca air, dapat diketahui apakah suatu DAS mengalami kelebihan (surplus) atau defisiensi (defisit) air. Analisis kesetimbangan air yan dapat diketahui besarnya surplus atau defisit dapat digunakan dalam membantu penanganan permasalahan ketersediaan maupun kebutuhan air seperti banjir dan kekeringan.

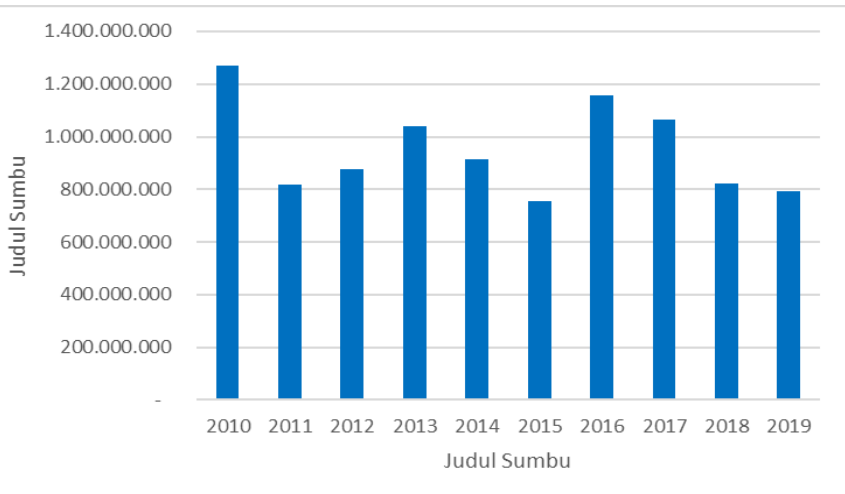

Gambar 10. Grafik Ketersediaan Air Permukaan DAS Bodri Tahun 2010-2019

Sumber: Data Debit Balai PSDA Bodri Kuto 2010-2019 (diolah)

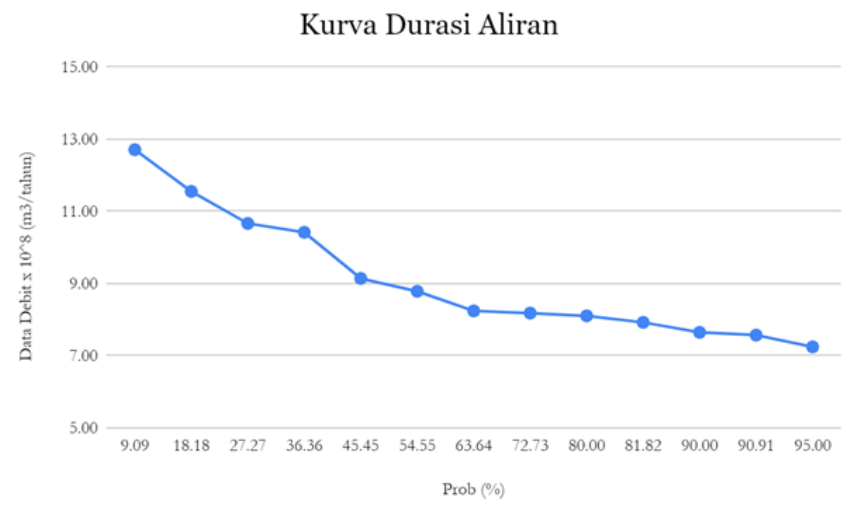

Gambar 11. Kurva Durasi Aliran DAS Bodri Sumber: Data Debit Balai PSDA Bodri Kuto 2010-2019 (diolah)

Neraca air DAS Bodri divisualisasikan dengan grafik antara variabel kebutuhan air dan ketersediaan air permukaan di DAS Bodri untuk periode 2010-2019 (Gambar 12). Berdasarkan grafik tersebut dapat diketahui bahwa neraca air pada DAS Bodri setiap tahunnya mengalami defisit. Hal ini terjadi karena kebutuhan air tiap tahunnya yang lebih tinggi dibandingkan dengan nilai ketersediaan air permukaan dengan rentang nilai kebutuhan air sebesar 2,06 miliar $\mathrm{m}^{3}$ hingga 2,95 miliar $\mathrm{m}^{3}$. Untuk rentang nilai ketersediaan air permukaan sebesar $0,76 \mathrm{~m}^{3}$ hingga $1,27 \mathrm{~m}^{3}$. Oleh karena itu rentang nilai defisit dari tahun 2010 hingga tahun 2019 berkisar antara 1,02 miliar $\mathrm{m}^{3}$ hingga 2,00 miliar $\mathrm{m}^{3}$. Defisit maksimum pada DAS ini terjadi pada tahun 2012 dan defisit minimum pada tahun 2013.

Terjadinya defisiensi air untuk memenuhi kebutuhan air di DAS Bodri pada tahun 2010-2019 menunjukkan bahwa pemenuhan kebutuhan air tidak bisa bergantung pada sumberdaya air permukaan (sungai) mengingat kebutuhan air terus meningkat hingga mencapai 2,43 miliar $\mathrm{m}^{3}$ pada tahun 2040. Kebutuhan air pada tahun 2040 diproyeksikan sebesar 2.435.065.691,97 m3. Jika dibandingkan dengan debit andalan sebesar 810.497.236,10 $\mathrm{m}^{3}$, maka DAS Bodri belum mampu memenuhi kebutuhan pada tahun 2040. Kebutuhan air pada tahun 2040 sulit terpenuhi apabila hanya bergantung pada air sungai. Salah satu andil pemerintah setempat dalam pemenuhan kebutuhan air untuk kehidupan masyarakatnya 


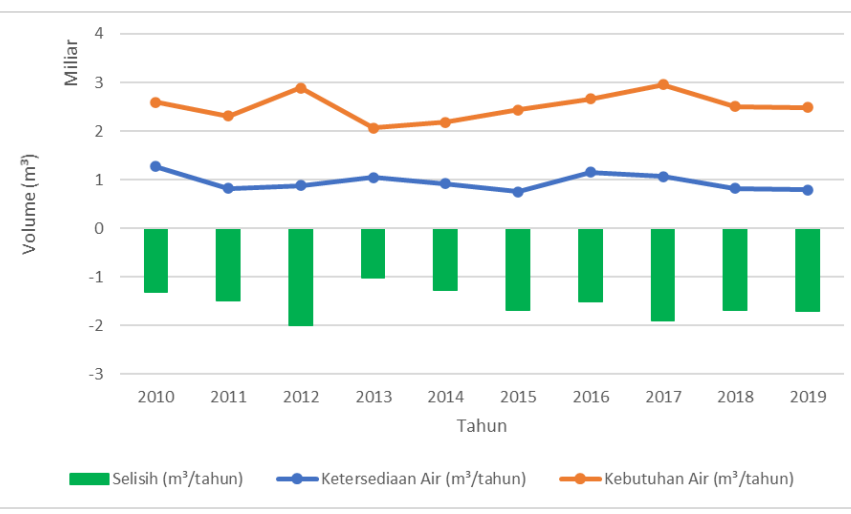

Gambar 12. Neraca Air DAS Bodri Tahun 2010-2019

Sumber: Data Kebutuhan dan Ketersediaan Air Permukaan DAS Bodri Tahun 2010-2019

yaitu dengan adanya pembangunan Waduk Bodri berkapasitas 41,82 juta $\mathrm{m}^{3}$ yang ditargetkan rampung pada tahun 2022 seperti dilansir dari BBWS Pemali Juana (2018). Dengan mempertimbangkan kebutuhan air pada tahun 2040, debit andalan, dan kapasitas rencana Waduk Bodri, maka dapat diketahui bahwa status neraca air di DAS Bodri masih mengalami defisiensi sebesar 1.592.499.035,60 $\mathrm{m}^{3}$. Hal tersebut membuktikan bahwa potensi sumberdaya air permukaan dari waduk yang direncanakan dan sungai belum mampu mencukupi kebutuhan air domestik dan non domestik di DAS Bodri.

\section{KESIMPULAN}

Berdasarkan hasil analisis untuk mencapai tujuan, kesimpulan dalam penelitian ini yaitu kebutuhan air domestik untuk 4 tahun pertama mengalami fluktuasi dan setelah tahun 2013 mengalami peningkatan. Proyeksikan kebutuhan air yang dibutuhkan penduduk untuk aktivitas domestik mencapai 24,4 juta $\mathrm{m}^{3}$. Volume air yang dibutuhkan untuk aktivitas non domestik di DAS Bodri melebihi kebutuhan air domestik yang disebabkan oleh permintaan kebutuhan dari berbagai sektor kegiatan meliputi fasilitas publik, sektor komersial, dan sektor agrikultur. Pada tahun 2040, kebutuhan air non domestik diestimasikan mencapai kurang lebih 2,44 miliar $\mathrm{m}^{3}$. Berdasarkan perhitungan kebutuhan dan ketersedian air di DAS Bodri diketahui bahwa neraca air DAS Bodri pada tahun 2010-2019 mengalami defisit 1,03 miliar $\mathrm{m}^{3}$ hingga 2,01 miliar $\mathrm{m}^{3}$.

Hasil analisis neraca air DAS Bodri menunjukkan bahwa sungai di DAS Bodri belum mampu memenuhi kebutuhan air. Hal tersebut dibuktikan melalui perbandingan debit andalan dengan keandalan $80 \%$ dengan proyeksi kebutuhan air tahun 2040. Defisiensi air pada periode tersebut mengindikasikan adanya kekhawatiran dalam pemenuhan kebutuhan air di DAS Bodri untuk tahun-tahun kedepannya. Rencana pembangunan Waduk Bodri dapat menambah ketersediaan air permukaan dimana waduk tersebut dibangun dengan kapasitas 41,82 juta $\mathrm{m}^{3}$. Meskipun begitu, hal tersebut belum sebanding dengan jumlah kebutuhan air yang diproyeksikan pada tahun 2040. Dengan demikian, potensi sumberdaya air permukaan di DAS Bodri belum mampu memenuhi kebutuhan air total di DAS Bodri.

\section{UCAPAN TERIMA KASIH}

Ucapan terima kasih kami sampaikan kepada Dr. Mohammad Pramono Hadi, M.Sc sebagai dosen pembimbing yang telah memberikan arahan kepada kami.Ucapan terimakasih juga penulis sampaikan kepada Pemerintah Kabupaten Kendal dan BPSDA Bodri Kuto Semarang yang telah membantu kami dalam memperolah data penelitian ini.

\section{DAFTAR PUSTAKA}

Afrianto, L, \& Rohmat, D. (2015). Proyeksi Kebutuhan Air Bersih Penduduk Kecamatan Indramayu Kebuapten Indramayu Sampai Tahun 2035. Antologi Geografi. 3(3).

Altarans dan Pradoto (2018), Urban Compactness Di Wilayah Perkotaan Kendal. Jurnal Pembangunan Wilayah \& Kota. 14(4) 281-293.

https://doi.org/10.14710/pwk.v14i4.17822

Anna, N.A., Dwi Priyono, K., Priyana Jl Yani Tromol Pos, Y. A., \& Surakarta, P. (2016). Using Water Balance to Analyze Water Availability for Communities ( A Case Study in Some Areas of Bengawan Solo Watershed). Forum Geografi, 30(2), 166-175. https://doi.org/10.23917/forgeo.v30i2.2550.

Asdak, C. (2007). Hidrologi dan Pengelolaan Daerah Aliran Sungai. Yogyakarta: Gadjah Mada University Press.

Azizah, L., Supandi, \& Surryanto, D. . (2019). Electronic commerce (E-Commerce) Dalam Perspektif Ekonomi Pertahanan. Jurnal Ekonomi Pertahanan, 5(2), 275-296. https://doi.org/10.1016/ s0267-3649(97)80172-0

Badan Pengembangan Sumber Daya Masyarakat PU. (2018).Modul Proyeksi Kebutuhan Air dan Identifikasi Pola Fluktuasi Pemakaian Air. Diambil dari https:// bpsdm.pu.go.id/center/ pelatihan/uploads/

edok/2018/11/920dd_2.Proyeksi_Kebutuhan_Air_dan_Identifik asi_Pola_Fluktuasi_Pemakaian_Air.pdf

Badan Pusat Statistik (BPS). (2011). Kabupaten Kendal Dalam Angka 2011. Jakarta: BPS.

Badan Pusat Statistik (BPS). (2011). Kabupaten Semarang Dalam Angka 2011. Jakarta: BPS.

Badan Pusat Statistik (BPS). (2011). Kabupaten Temanggung Dalam Angka 2011. Jakarta: BPS.

Badan Pusat Statistik (BPS). (2011). Kabupaten Wonosobo Dalam Angka 2011. Jakarta: BPS.

Badan Pusat Statistik (BPS). (2012). Kabupaten Kendal Dalam Angka 2012. Jakarta: BPS.

Badan Pusat Statistik (BPS). (2012). Kabupaten Semarang Dalam Angka 2012. Jakarta: BPS.

Badan Pusat Statistik (BPS). (2012). Kabupaten Temanggung Dalam Angka 2012. Jakarta: BPS.

Badan Pusat Statistik (BPS). (2012). Kabupaten Wonosobo Dalam Angka 2012. Jakarta: BPS.

Badan Pusat Statistik (BPS). (2013). Kabupaten Kendal Dalam Angka 2013. Jakarta: BPS.

Badan Pusat Statistik (BPS). (2013). Kabupaten Semarang Dalam Angka 2013. Jakarta: BPS.

Badan Pusat Statistik (BPS). (2013). Kabupaten Temanggung Dalam Angka 2013. Jakarta: BPS.

Badan Pusat Statistik (BPS). (2013). Kabupaten Wonosobo Dalam Angka 2013. Jakarta: BPS.

Badan Pusat Statistik (BPS). (2014). Kabupaten Kendal Dalam Angka 2014. Jakarta: BPS.

Badan Pusat Statistik (BPS). (2014). Kabupaten Semarang Dalam Angka 2014. Jakarta: BPS.

Badan Pusat Statistik (BPS). (2014). Kabupaten Temanggung Dalam Angka 2014. Jakarta: BPS

Badan Pusat Statistik (BPS). (2014). Kabupaten Wonosobo Dalam Angka 2014. Jakarta: BPS.

Badan Pusat Statistik (BPS). (2015). Kabupaten Kendal Dalam Angka 2015. Jakarta: BPS.

Badan Pusat Statistik (BPS). (2015). Kabupaten Semarang Dalam Angka 2015. Jakarta: BPS. 
Badan Pusat Statistik (BPS). (2015). Kabupaten Temanggung Dalam Angka 2015. Jakarta: BPS.

Badan Pusat Statistik (BPS). (2015). Kabupaten Wonosobo Dalam Angka 2015. Jakarta: BPS.

Badan Pusat Statistik (BPS). (2016). Kabupaten Kendal Dalam Angka 2016. Jakarta: BPS.

Badan Pusat Statistik (BPS). (2016). Kabupaten Semarang Dalam Angka 2016. Jakarta: BPS.

Badan Pusat Statistik (BPS). (2016). Kabupaten Temanggung Dalam Angka 2016. Jakarta: BPS.

Badan Pusat Statistik (BPS). (2016). Kabupaten Wonosobo Dalam Angka 2016. Jakarta: BPS.

Badan Pusat Statistik (BPS). (2017). Kabupaten Kendal Dalam Angka 2017. Jakarta: BPS.

Badan Pusat Statistik (BPS). (2017). Kabupaten Semarang Dalam Angka 2017. Jakarta: BPS.

Badan Pusat Statistik (BPS). (2017). Kabupaten Temanggung Dalam Angka 2017. Jakarta: BPS.

Badan Pusat Statistik (BPS). (2017). Kabupaten Wonosobo Dalam Angka 2017. Jakarta: BPS.

Badan Pusat Statistik (BPS). (2018). Kabupaten Kendal Dalam Angka 2018. Jakarta: BPS.

Badan Pusat Statistik (BPS). (2018). Kabupaten Semarang Dalam Angka 2018. Jakarta: BPS.

Badan Pusat Statistik (BPS). (2018). Kabupaten Temanggung Dalam Angka 2018. Jakarta: BPS.

Badan Pusat Statistik (BPS). (2018). Kabupaten Wonosobo Dalam Angka 2018. Jakarta: BPS.

Badan Pusat Statistik (BPS). (2019). Kabupaten Kendal Dalam Angka 2019. Jakarta: BPS.

Badan Pusat Statistik (BPS). (2019). Kabupaten Semarang Dalam Angka 2019. Jakarta: BPS.

Badan Pusat Statistik (BPS). (2019). Kabupaten Temanggung Dalam Angka 2019. Jakarta: BPS.

Badan Pusat Statistik (BPS). (2019). Kabupaten Wonosobo Dalam Angka 2019. Jakarta: BPS.

Badan Pusat Statistik (BPS). (2020). Kabupaten Kendal Dalam Angka 2020. Jakarta: BPS.

Badan Pusat Statistik (BPS). (2020). Kabupaten Semarang Dalam Angka 2020. Jakarta: BPS.

Badan Pusat Statistik (BPS). (2020). Kabupaten Temanggung Dalam Angka 2020. Jakarta: BPS.

Badan Pusat Statistik (BPS). (2020). Kabupaten Wonosobo Dalam Angka 2020. Jakarta: BPS.

Badan Pusat Statistik. (2020). Statistik Penyedian Makanan dan Minuman 2018. Jakarta: BPS.

Badan Standarisasi Nasional. (2002). SNI 19-6728.1-2002. Penyusunan Neraca Sumber Daya. Jakarta: Badan Standarisasi Nasional.

Badan Standarisasi Nasional. (2015). Standar Nasional Indonesia (SNI) 6738:2015 Tentang Perhitungan Debit Andalan Sungai Dengan Kurva Durasi Debit. Jakarta: Badan Standarisasi Nasional.

BBWS Pemali Juana. (2018). Laporan Akhir Pekerjaan: Studi Kelayakan Bendungan Bodri Kabupaten Kendal. Semarang: PT. Mettana.

Dinas Pekerjaan Umum. 1996. Kriteria Perencanaan Ditjen Cipta Karya tahun 1996. Jakarta: Dinas PU.

Dinas Pusdataru Jateng. (2018). Data Hujan stasiun Pos KlimatJuwero Kabupaten Kendal. [Daring] tersedia dari: http:// pusdataru.jatengprov.go.id/opendata/dataset/data-hujanstasiun-pos-klimat-juwero-kabupaten-kendal-0 (diakses pada 15 Januari 2021)

Emilia, F., Hendrarto, B., \& Taruna, T. (2013). Pengelolaan Sumber Daya Alam Berbasis Masyarakat Dalam Upaya Konservasi Daerah Aliran Sungai: Studi Kasus Desa Keseneng, Kecamatan Sumowono, Kabupaten Semarang, Jawa Tengah. Bonorowo Wetlands, 3(2), 73-100. https://doi.org/10.13057/bonorowo/ w030202.

Hanafi \& Yosananto. (2018). Kajian Ketersediaan Air di Sungai
Cimande untuk Kebutuhan Air bagi Masyarakat di Kecamatan Cimanggung Sumedang. RekaRacana:Jurnal Teknik Sipil. 4(1), 112-121. https://doi.org/10.26760/rekaracana.v4i1.112.

Hasmannoor, M. (2018). Potensi Kuantitas Air Tanah Pada Cekungan Airtanah Kendal, Kabupaten Kendal, Provinsi Jawa Tengah. Yogyakarta: Universitas Gadjah Mada.

Keputusan Menteri Kehutanan RI. (2009). Keputusan Menteri Kehutanan RI No. SK.328/Menhut-II/2009 tentang Penetapan Daerah Aliran Sungai (DAS) Prioritas Dalam Rangka Rencana Pembangunan Jangka Menengah (RPJM) Tahun 2010-2014. Jakarta: Kementerian Kehutanan.

Kumalajati, E., Sabarnudi, S., Budiadi, B., \& Sudira, P. (2015). Analisis Kebutuhan Dan Ketersediaan Air Di Das Keduang Jawa Tengah. Jurnal Teknosains, 5(1), 9. https://doi.org/10.22146/ teknosains.26854

PT Sarana Multi Infrastruktur. (2015). Indonesia Water Investment Roadmap 2011-2014. [Daring] tersedia dari: https:// www.ptsmi.co.id/wp-content/uploads/2018/09/ SMI_Insight_Q2_2017_

ENG.pdf (diakses pada 15 Januari 2021)

Pusdiklat SDA \& Konstruksi. (2017). Pelatihan Dasar Teknis Bidang Sumberdaya Air: Pemberdayaan Masyarakat. Kementerian Pekerjaan Umum dan Perumahan Rakyat.

Salim, M. A. (2019). Analisis Kebutuhan dan Ketersediaan Air Bersih (Studi Kasus Kecamatan Bekasi Timur) (Universitas Islam Negeri Syarif Hidayatullah). Diambil dari http:// repository.uinjkt.ac.id/dspace/bitstream/123456789/46503/1/ MUHAMAD AGUS SALIM-FITK.pdf

Setyowati,D. L..(2010). Hubungan Hujan dan Limpasan Pada Sub DAS Kecil Penggunaan Lahan Hutan, Sawah, Kebun Campuran di DAS Kreo. Forum Geografi, 24(1), 39-56.

Sitompul, M., \& Efrida, R. (2018). Evaluasi Ketersediaan Air DAS Deli Terhadap Kebutuhan Air (Water Balanced). Jurnal Rekayasa Sipil (JRS-Unand), 14(2), 121. https:// doi.org/10.25077/jrs.14.2.121-130.2018.

Subramanya, K. (2008) Engineering Hydrology. New Delhi: Tata McGraw-Hill Publishing Company Limited,

Sudarmadji, Hadi, P., \& Widyastuti, M. (2014). Pengelolaan Sumberdaya Air Terpadu. Yogyakarta: Gadjah Mada University Press.

Tisnasuci, I. D., Sukmono, A., \& Hadi, F. (2021). Analisis pengaruh perubahan tutupan lahan Daerah Aliran Sungai Bodri terhadap debit puncak menggunakan metode Soil Conservation Service (SCS). Jurnal Geodesi, 10(1), 105-114.

Wahyuni, A., \& Junianto. (2017). Analisa Kebutuhan Air Bersih Kota Batam pada Tahun 2025. TAPAK. 6(2) 116-126.

Wilonoyuhdo, S. (2010). Urbanisasi dan Dampak Lingkungan di Koridor Kendal-Semarang-Demak. Jurnal Manusia dan Lingkungan. 17(3) 173-182. 